\title{
The development of voluntary private health insurance in the Nordic countries
}

\author{
NINA ALEXANDERSEN ${ }^{1}$ \\ ANDERS ANELL ${ }^{2}$ \\ ODDVAR KAARBOE ${ }^{1, *}$ \\ JUHANI S. LEHTO ${ }^{3}$ \\ LIINA-KAISA TYNKKYNEN ${ }^{4}$ \\ KARSTEN VRANGB $Æ K^{5}$ \\ ${ }^{1}$ Department of Health Management and Health Economics, University of Oslo, Norway \\ ${ }^{2}$ Department of Business Administration, Lund University, Sweden \\ ${ }^{3}$ School of Health Sciences, University of Tampere, Finland \\ ${ }^{4}$ Institute for Advanced Social Research, University of Tampere, National Institute for Health and Welfare, \\ Finland \\ ${ }^{5}$ Department of Political Science and Department of Public Health, University of Copenhagen, Denmark
}

\begin{abstract}
The Nordic countries represent an institutional setting with tax-based health care financing and universal access to health care services. Very few health care services are excluded from what are offered within the publically financed health care system. User fees are often non-existing or low and capped. Nevertheless, the markets for voluntary private health insurance (VPHI) have been rapidly expanding. In this paper we describe the development of the market for VPHI in the Nordic countries. We outline similarities and differences and provide discussion of the rationale for the existence of different types of VPHI. Data is collected on the population covered by VPHI, type and scope of coverage, suppliers of VPHI and their relations with health providers. It seems that the main roles of VPHI are to cover out-of-pocket payments for services that are only partly financed by the public health care system (complementary), and to provide preferential access to treatments that are also available free of charge within the public health care system, but often with some waiting time (duplicate).
\end{abstract}

JEL classification: I11, I13

Key words: voluntary private health insurance, complementary private health insurance, duplicate private health insurance, tax-policies

\section{Introduction}

The Nordic countries are well known for their welfare states. An important feature of the welfare state ethos is easy and equal access to adequate healthcare for the whole population. Very few services are defined outside the public health care system, the user co-payments are relatively low and complemented with an annual high-cost ceiling. Instead of using

* Correspondence to: Oddvar Kaarboe, HELED, UIO. P.O. BOX 1089, Blindern, 0317 Oslo. E-mail: oddvar.kaarboe@medisin.uio.no

dx.doi.org/10.5617/njhe. 2718 
financial incentives to reduce demand the health care systems have been characterized by rationing by waiting time and gate-keeping to specialized care.

In spite of the apparent similarities of the Nordic health care systems, there are differences between the countries in terms of governance/organization and financing of the health services. ${ }^{1}$

The Finnish public health system is built on three parts: The first part is a tax funded system run by the municipalities with public and some outsourced private providers. Specialist care is provided by 20 regional providers, hospital districts. The second part is an obligatory public health insurance (PHI) based system reimbursing the use of privately provided health services. It covers all permanent residents in Finland. The PHI funded system mainly provides services that are duplicate to the tax funded services. Waiting times are either non-existent or much shorter than in the tax funded system, but co-payments are significantly higher. The third part is that employers are obliged to organize preventive occupational health care services for their employees. Many employers also purchase medical outpatient services for their staff. These services are reimbursed partly by National Health Insurance. Occupational health care services, unlike other first contact services in Finland, are free of charge for the users.

Norway is characterized by a semi-decentralized health care system. The municipalities hold responsibility for primary care while the central government, represented by four regional health authorities, governs specialist care. Both primary and specialized care are tax funded.

Denmark also has a semi-centralized health care system. Since 2007 specialized care is mainly provided by hospitals owned and run by five regions. General practitioners and practicing specialists are privately owned, but operate under general contracts with the regions and receive most of their income from public sources generated by taxation at the state and municipal levels. Both general and practicing specialists are subject to regional planning in terms of the number and location of practices.

In Sweden the responsibility for financing and provision of health services lies at the county councils/regions, while municipalities are required to provide care for the aged and disabled. Most health care is financed through local taxation, and contrary to Denmark and Norway, county councils have the right to collect their own taxes.

Access to specialist care in Denmark and Norway is controlled by gatekeeping. That is, by general practitioners that refer patients to the specialists. In Sweden, the majority of county councils do not formally require referrals to enter specialized care, although patients are encouraged to seek primary care first. In Finland referrals are not required if a person visits the private sector specialists (PHI system).

As the populations in the Nordic countries have become older and richer, demand for, and expenditure of, health care has grown more than the increase in resources. Governments in the Nordic countries have introduced reforms on both the demand side and the supply side of the health care sector to cope with limited capacity and long waiting times.

On the supply side, increased funding to health care, waiting-time guarantees and prospective reimbursement, such as activity-based financing using diagnoses-related groups, are some of the policies that have been introduced. However, these policies have generally been unsuccessful in bringing down waiting times. Even policies of activity-based financing do not necessarily decrease waiting times, although hospital productivity

\footnotetext{
${ }^{1}$ We use the term Nordic countries, even though we only include Denmark, Finland, Norway and Sweden in the overview that follows. The reason that Iceland is not included is that voluntary private health insurance is hardly existing on Iceland. According to the OECD Health Statistics (2015), 0,2\% of the population on Iceland were covered by private health insurance.
} 
generally increases (Siciliani et al, 2013). Introduction of activity-based financing is however a key component in introducing choice and competition, which may in itself reduce waiting times. In addition choice and competition will increase the inhabitants' option of providers, and may utilize capacity available in the private sector.

The demand side reforms typically imply increased out-of-pocket payments and increased cost-sharing for services that are partly covered by the public system. The main rationale, in addition to contain public expenditure expansion, has been to make people more aware of the cost of medical services thus preventing overutilization. In addition, increased out-of-pocket payments for (price-inelastic) services will also increase the financial resources available for the health care sector. The other demand side policy approach has been to shift demand to the private sector. One example of such a policy is to stimulate the growth of voluntary private health insurances (VPHI) by introducing tax incentives for employees and employers.

The VPHI schemes that are introduced in the Nordic countries are mainly complementary or duplicate in relation to the public health care system. That is, the VPHI schemes cover out-of-pocket payments for services that are only partly financed by the public health care system (complementary), or they provide preferential access to treatments that are also available free of charge within the public health care system, but often with some waiting time (duplicate). In addition some of the VPHI schemes also offer supplementary health services. That is, services not covered by the public health care system (OECD, 2004).

The purpose of this paper is to describe the development of the VPHI in the Nordic countries. We will highlight similarities and differences related to population coverage, the type and scope of coverage, the suppliers of VPHI and their relationship with health care providers. Furthermore we will outline whether tax-policies have been introduced to promote VPHI. We provide discussion of the rationale for the existence of different types of the VPHI. Finally we indicate possible avenues for future research related to VPHI in the Nordic countries.

\section{Potential benefits and drawbacks of VPHI}

One of the main benefits of VPHI is that it may shift demand from the public health care sector to the private sector. In this case VPHI might increase available capacity, reducing waiting times and releasing financial pressure from the public system since those with private insurance will cover some of the medical expenses themselves. In addition, VPHI may demonstrate more flexibility and responsiveness to population needs and preferences by providing patients with faster access and increased choice of providers. VPHI may also provide access to services excluded from the public coverage. Private insurers can provide patients with effective guidance trough complicated health care system and promote more efficient utilization of available capacity in the public and private sectors. Finally, it can lead to more dynamic and competitive market with a higher degree of innovation; improve efficiency, quality and sustainability of the public system and enhance access (Colombo and Tapay, 2004).

In spite of the number of potential positive consequences, these effects have not yet been consistently demonstrated (Sagan and Thomson 2015). Moreover, there are concerns and challenges associated with the expansion of private sector health services that need to be addressed. VPHI may reduce capacity by crowding out resources from the public system. It may lead to distortion in resource allocation and priorities, and result in overutilization of services. These concerns are particularly relevant when there is a limited supply of 
physicians and borders between public and private systems are not clearly defined (Mossialos and Thomson, 2004).

Competitive market environments may further increase pressure on the public system if VPHI gives insurers and private providers opportunities for risk selection thus leaving the public sector with patients that require more costly treatments. VPHI may also work against the policy goal of making patients/physicians more conscious of the use of services thus potentially resulting in excessive utilization of services.

The expansion of VPHI in the Nordic countries, as well as in other countries with national health care systems, has been subject to debate as VPHI is often bought by individuals of higher socioeconomic status (see e.g. Kiil (2012)). In this respect, VPHI can lead to medical care divided by social class (Manifest, 2009) and priorities determined by the individuals' financial/insurance status. It is also argued that higher income groups (that purchase VPHI and pay taxes) might be less motivated to contribute to the public system in the future.

Despite that expansion of VPHI has a potential for addressing the current challenges in the Nordic health care systems and in theory sounds promising, it is important to be aware of its potential negative effects and monitor its development to ensure that it does not violate important societal goals such as equity and solidarity and does not adversely affect efficiency, coordination and sustainability of the public system.

\section{The institutional framework of VPHI}

In the following we will present data on the population covered, type and scope of coverage, suppliers of VPHI and their relationship with health care providers for Finland, Denmark, Norway and Sweden.

\subsection{Population covered with VPHI}

The market for VPHI has grown significantly in the Nordic countries. Currently about $20 \%$ of the population in Finland is covered by VPHI. The corresponding numbers for Denmark, Norway and Sweden are respectively $51 \%, 9 \%$ and $7 \%$.

According to the Finnish Federation of Financial Services 438421 children had private insurance for health care costs, 363382 adults had private insurance and 171007 had private insurance through an employer in 2013 (FFFS 2013). ${ }^{2}$ The growth has been significant the latter years. ${ }^{3}$

In Norway, the market for VPHI was almost non-existent until the beginning of the millennium. Since then the market has rapidly expanded. In 2015, 472000 individuals were covered (Finans Norge, 2015a). Collective/group policies constitute around $90 \%$, while $10 \%$ are individual policies.

In Sweden, 626000 people had VPHI at the end of 2015. This is an increase from 218000 in 2006. $72 \%$ of insurance policies were paid by the employer. The remaining policies were divided between individually purchased, $5 \%$, and group policies, $23 \%$ (Svensk Försäkring, 2015). Group policies, which contributes to the most of the market expansion in recent years, are signed by employers, unions or other member organizations, but paid by individuals.

\footnotetext{
${ }^{2}$ In the first survey of health insurance in Finland it is estimated that $22.7 \%$ of Finnish adults and $52 \%$ of the children had private health insurance. Of the insured adults, $74.8 \%$ had self-purchased health insurance, $16.2 \%$ employer-purchased health insurance and $9 \%$ both, Valtonen et al. (2014).

${ }^{3}$ In 2005, 375000 children and 237000 adults had voluntary private health insurance, Vuorenkoski (2008).
} 
In Denmark, complementary VPHI has played a significant role since the early 1970s while duplicate VPHI is a more recent phenomenon. ${ }^{4}$ Complimentary insurance was held by 2.3 million Danes in 2014 (Health insurance 'danmark', Annual report 2014).

The number of inhabitants with duplicate treatment insurance has increased from 230000 in 2003 to 2 million in 2014. In most cases (about $75 \%$ ) duplicate insurance is part of an employment contract. The number of persons covered by individual policies is low and decreasing (from $4 \%$ in 2003 to $1.8 \%$ in 2013). The remaining (23.5\%) are covered by treatment insurance contracts where partners and children are co-insured (Forsikring \& Pension, 2014a).

About $37 \%$ of those with complementary VPHI also had medical treatment insurance. It is therefore estimated that 2.9 million inhabitants were covered by private health insurance, CEPOS (2014).

\subsection{Type and scope of coverage}

\subsubsection{Complementary VPHI}

Complementary VPHI plays a significant role in Finland and Denmark, while in Norway and Sweden this type of coverage is almost non-existent. Complementary health insurance is defined as private health insurance that complements coverage of the public sector services by covering all or part of the residual costs not otherwise reimbursed (OECD, 2015).

A distinct feature of the complementary insurance in Finland is that it can provide a faster access to primary ${ }^{5}$ and secondary care level ambulatory services and direct access to a specialist without a referral from $\mathrm{GP}^{6}$. In other Nordic countries primary care is usually excluded from the coverage. In Finland, VPHI is largely complementary to the use of privately provided health services reimbursed by the obligatory PHI based system through which the visits, diagnostic and treatment services, and prescription drugs are reimbursed to a small extent. However, while VPHI is mostly used to cover the high co-copayments in the PHI reimbursed system it usually covers also co-payments in the municipal primary care centers and public hospitals.

The complementary insurance in Denmark covers co-payments for pharmaceuticals, and services such as adult dental services, glasses and contact lenses, and physiotherapy (Pedersen, 2005). The total compensations related to complementary co-payment insurance in Denmark amounted to 2649 million Danish kroner (€355 mill.) in 2014, compared to around 25000 million Danish Kroner in total private user payments.

\subsubsection{Duplicate VPHI}

Duplicate private coverage exists in all Nordic countries. It plays a major role in Norway and Sweden. Duplicate VPHI offers coverage for health services already included under government health insurance, while also offering access to different providers (e.g., private hospitals) or levels of service (e.g., faster access to care). It does not exempt individuals from contributing to government health coverage programs, OECD (2015).

\footnotetext{
${ }^{4}$ Duplicate insurance is called supplementary in Denmark and includes both duplicate and supplementary services. The information and numbers below are for treatment insurance that covers both types of services. ${ }^{5}$ With VPHI patients can access private sector in which there are doctors that can be seen as parallel to GPs in a sense that they are either not specialists or they are specialists in general practice. Most of the doctors working in the private sector are however specialists in other than general practice. The access in turn resembles the primary care in a sense that it is the place for first-contact-care. The physicians in the private sector can also refer patients to public hospitals which also features primary care.

${ }^{6}$ The direct access applies only to those specialists working in the private sector.
} 
As already described, in Finland, use of private health services is partly reimbursed by the obligatory public health insurance. This system is often duplicate to the municipal system but it offers better access to care and often also a direct access to a specialist. In addition, the use of the private services partly reimbursed from the PHI allows the choice of a doctor and provider organization in the private sector. However, the co-payments are relatively high since PHI is covering only around $20-30 \%$ of the costs. Hence, by purchasing a VPHI the individual can have more affordable services compared to PHI but also better access compared to the municipal system. However, not all services are included in VPHI. Services that are often excluded include prenatal examinations, terminations, delivery, fertility treatment, contraception, visual examinations and treatment of refractive error, vaccinations, vitamins or other health foods and nutrients, esthetic surgery, treatment of virility and 'alternative' treatments. The insurance companies may exclude treatment of specific diseases on the basis of individual exclusion criteria. This is usually based on the case history of the insured person, i.e. existing medical conditions before purchase of VPHI are usually excluded. Typical conditions that are excluded at purchase are type one diabetes and other chronic diseases. For children, conditions such as congenital medical conditions and disabilities may be excluded.

In Denmark there are several types of VPHI. The majority of policies provide faster access to specialist diagnosis and treatment services that are also available in the public system. They cover expenses for examinations and treatments (including surgery and medicines) at private hospitals, preventive services by physiotherapists and chiropractors, and general health examinations. Around 33\% of all policies are less comprehensive, and only cover diagnostic and preventive services. Most policies do not cover ongoing medication for chronic conditions, but do cover medication related to acute treatment episodes and some follow up (Interview with "Forsikring og Pension", ${ }^{7}$ January 27, 2016).

Policies on exclusion of products vary between companies, but generally all treatments that are covered in the public sector and can lead to sustained health benefits are covered (interview with "Forsikring og Pension", January 27 2016). Most collective policies exclude medication for chronic conditions and/or define a specific period (12-24 months) before coverage starts for preexisting conditions. Cosmetic surgery is typically excluded as in the public system, and infertility treatment is excluded or subject to limitations.

VPHI in Denmark increases the choice of provider, but the choice can be limited to the provider network that is associated with a particular insurer. As a rule a referral is required to access specialist care in Denmark. However, some private insurance policies do not require referrals. In Denmark there is also an option in the public system to select a coverage scheme that provides direct access to privately practicing specialists. Patients within this scheme receive reimbursement up to the level of public fees, but must pay an additional fee.

In Norway, VPHI provides the insured guaranteed access to medical examination or treatment by a specialist physician/elective surgery within a specified time frame. VPHI typically covers diagnostics, examinations, specialist consultations and treatments, hospitalizations and elective surgeries as well as rehabilitation. In addition, physiotherapy and psychological treatment can be included. VPHI will typically not include emergency treatments, treatments at public facilities like hospitals and primary care centers, psychiatric treatment, dental treatment, addictions related to alcohol, drugs, sleep agents or narcotic substances, pregnancy-related treatments, deliveries, abortion and sterilization, infertility treatments, sleep-related treatment, obesity, cosmetic treatments, examination and treatment related to vision as well as vision and hearing aids, vaccination and preventive examination.

\footnotetext{
7 "Forsikring og Pension" is the business association for private insurance and pension providers in Denmark.
} 
In addition, VPHI will typically not cover services that are excluded from the public coverage. Most insurers exclude preexisting conditions and define a specific period between the purchase of VPHI and the time from which coverage starts to apply. This is particularly the case for individual policies and small groups policies.

In Norway VPHI increases the choice of providers in specialist care. However, the choice of provider is usually restricted to the provider network that a particular insurance company has established a collaboration with. Insurance companies usually have a service unit that looks for available capacity and coordinate all patients' treatment activities. In cases when there is a lack of capacity or competence, provider networks can be expanded. As a rule insurance companies in Norway also require referral from a primary care physician to access secondary/specialist care. In some cases, the insured will have an opportunity to receive a 'second opinion', particularly in case of life-threatening conditions or a risky treatment.

One company in Norway 'Vertikal Helse' offers a special mediation service that is included in the health insurance package they offer. This service is unique since it provides assistance within a wide range of services, including those not covered by the insurance, to find the most appropriate and competent health care provider. The search will include both public and private providers in Norway as well as providers in the Nordic countries and Europe. Those who buy this type of service can get discounted prices for medical services within the insurers' provider network.

In Sweden, VPHI typically covers health care advice, care planning and coordination and specialist care with a focus on elective surgeries and rehabilitation (Svensk Försäkring, 2013). Many insurance companies are also offering preventive care to increase health and wellbeing among employees and to prevent sickness absents. Examples of such services include programs to reduce stress and support changes towards a healthy lifestyle, and counseling from behavioral therapists or psychologists. Private insurers in Sweden follow similar practices on exclusion of treatments as Norwegian insurers. The main services that are excluded relate to acute treatment and highly specialized services. Insurers in Sweden may exclude preexisting conditions. The choice of a health care provider is usually limited to private providers within the insurer's network and can be also restricted to the providers that operate in Sweden. VPHI in Sweden (in contrast to Norway) does not require a referral from a GP to access specialist care, thus potentially removing barriers to direct access to a specialist care. Instead, care planning is often carried out through a triage function over the phone.

Co-payments for services provided through VPHI vary both within and between the countries. In Finland there are different arrangements for co-payments. The most common are: i) periodical co-payment that has to be covered out-of-pocket each policy period (usually a year); ii) disease related co-payment that is charged once per treated disease/condition; iii) co-payment that is charged every time reimbursement is claimed from an insurance company; iv) no-copayments. (The Finnish Financial Ombudsman Bureu 2014.).

In Norway, co-payments in the private sector may depend on the health insurance agreement/policy, but many insurers do not require copayments. Only a few policies in Denmark require co-payments. The insurance companies have attempted to introduce a deductible, but with limited success and competition has largely eliminated this (Interview with "Forsikring and Pension, January 27 2016).

In Sweden individuals are often required to pay co-payment for use of services. The level of co-payments varies but has generally increased in recent years (Skoglund, 2012). A common practice is that individuals pay 500 SEK or more in copayments for the first visit in a healthcare episode. 


\subsubsection{Supplementary VPHI}

The role of supplementary insurance is relative small in the Nordic countries. It provides coverage for additional health services not at all covered by the government/social scheme, OECD (2015).

In Finland VPHI has a very small supplementary element as some policies include services not covered by the publicly funded system. These include travelers' travel costs from outside Finland and policies concerning some luxury products. A part of VPHI policies only cover services needed due to sports accidents - these are marketed in cooperation with sports associations. For a number of sport activities, active participation is even conditional to having this kind of VPHI.

A slowly growing number of VPHIs in Finland are offered to employers to cover for employees or "key" employees services that are not accepted medical services covered by the PHI funds according to the occupational health law. Another group of people targeted by VPHI is people at the "third age", leaving the coverage offered by occupational health. There are also certain sickness specific insurance products such as cancer insurances.

In Denmark supplementary health insurance is an integrated part of many commercial and non-commercial policies, but to varying degrees. It typically covers services in situations where the public sector does not cover, such as some types of physiotherapy, psychological therapy e.g. for stress related conditions and health check-ups.

In Norway supplementary VPHI hardly exists. If it is provided it is related to dental treatment for collective policies, gambling, drug and alcohol addiction, and some additional types of alternative treatments (e.g. acupuncture) provided by authorized personnel.

In Sweden supplementary services exist mainly for adult dental services. In exchange for a monthly risk-adjusted fee, individuals are offered dental care services free of charge. This supplementary service is usually offered at public dental clinics (Folktandvården) and are less common among private dental practices. The insurance covers general examinations, acute services and treatment of caries and tooth loss. Services such as tooth replacements, orthodontics and tooth whitening are not included. About 200.000 individuals had this insurance in 2011 and it is more common among young adults (Försäkringskassan 2012).

\subsection{Suppliers of VPHI ${ }^{8}$}

The major actors operating in the Finnish VPHI market are OP-Pohjola-group (31.7\%), LähiTapiola-group (24.9\%), If (24.7\%), and Fennia (9.8\%). All are for-profit companies. In addition a few smaller companies are active (The Federation of Finnish Financial Services 2015).

In Denmark, complementary VPHI is offered by the non-profit health insurer 'danmark'. This company had around 2.3 million members in 2014 (Sygeforsikring 'danmark' annual report 2014). Duplicate VPHI is mainly provided by commercial stockbased insurance companies. In addition, the non-profit insurer 'danmark' offers some policies with reimbursement of some expenses for elective surgeries at private hospitals. The companies that provide private health insurance in Denmark include PFA Pension (incl. Mølholm Insurance) (33.2 \%), Tryg (13.4\%), Danica (12.1\%), Skandia (10.1\%), Codan (9.8 \%), If (7.4\%), PensionDanmark (7.3\%), Topdanmark (6.6\%), Forsikring \& Pension (2014b).

The providers that offer VPHI in Norway are mainly for-profit insurance companies. The major actors operating in Norwegian market are: Codan Forsikring/Vertikal

\footnotetext{
${ }^{8}$ The percentages in this section indicate market shares in 2014.
} 
Helseassistanse (32.6\%), Storebrand Helseforsikring (18\%), If NUF (16.7 \%), Gjensidige Forsikring (13.6 \%) Tryg Forsikring (11\%) and SpareBank 1 (7.7 \%) (Finans Norge, 2014).

About 15 insurance companies are presently offering VPHI in Sweden. The number of VPHI products on the market is higher, however, as insurance companies usually offer more than one policy with differences in services covered, restrictions and deductibles. The four main actors in Sweden ${ }^{9}$ are Trygg-Hansa (38\%), Länsförsäkringar (19\%), Folksam (20\%) and If (11\%). Länsförsäkringar and Folksam are customer-owned companies, while Trygg-Hansa and If are for-profit companies.

\subsection{The relationship between suppliers of VPHI and health care providers}

\subsubsection{Payment to private health providers}

In Finland, policy holders usually disburse the expenditures and are reimbursed by insurers afterwards. In cases of expensive treatments the insurers usually pay directly to the private provider. In these cases the insurance company typically requires a preliminary approval of the treatments. Some insurance companies - such as LähiTapiola - have signed contracts with direct payment to private providers so the insured do not have to pay out-of-pocket.

In Norway privately insured patients usually pay for specialist consultations/services received through the insurers' provider network. They are later reimbursed by insurers. In some cases the insurers pay directly to the private providers. 'Storebrand Helseforsikring' for example pays directly to private providers (i.e. hospital or rehabilitation institution) in case of hospitalization (with and without surgery) as well as for cancer treatment.

In Denmark most policies do not require patients to pay out of pocket. This has changed over time in response to consumer preferences (interview with "Forsikring og Pension", January 27, 2016). Insurers do not provide access to detailed information about their contracts with providers as this is subject to competition.

In Sweden providers are usually paid directly from insurance companies, excluding deductibles that may be paid directly by individuals at the point of service. Insurance companies typically require approval of expensive diagnostic services and treatments.

\subsubsection{Contracting with private health providers}

Contracting between insurance companies and private providers is not common in Finland. The basic orientation is reimbursement. This is particularly true when it comes to reimbursement of private outpatient services.

However, there seems to be a movement towards stricter cost control of prices for surgeries and expensive diagnostic procedures. Some policies require that a patient only uses providers accepted by the insurance company. Should the patient use another provider (s)he has to cover the additional costs out-of-pocket. OP-Pohjola has established its own hospital (Omasairaala), and is further expanding by establishing a hospital chain in which their insured patients will be treated. The aim is to treat especially the high cost VPHI patients (e.g. surgery) in these hospitals. In this way OP-Pohjola is probably aiming at a better control over the costs of (inpatient) care.

In Norway, private health insurers usually selectively contract private health providers in Norway and the other Nordic countries. The choice of providers is based on their expertise, quality, available capacity and prices. However, the selective contracting might be limited as for-profit hospitals do not provide all kinds of treatment. When there is

\footnotetext{
${ }^{9}$ The market shares within brackets refers to "sjukvård och olycksfall" (health and accident insurance) i.e. a broader category of insurance including VPHI. However, these four actors is responsible for most of the market, and they are often referred to in comparisons between VPHI products.
} 
lack of capacity or competence in the Nordic countries, the insurance companies will include providers within their European network (preferably from the closest countries).

Prices are set through negotiations with providers and tendering. Payments are based on the services that are approved in long-term contracts. As a rule, insurers require that patients have a referral (some insurers specify that doctors have to practice in the Nordic countries). Moreover, insurers stipulate that all examinations and treatment expenses have to be approved in advance by the insurance company, and treatment must be performed in private hospitals within insurers' provider network. Policy holders receive assistance from trained medical personnel to make appointments with an appropriate specialist and to coordinate care. Through this process insurance companies also ensure that patients receive approved/reimbursable treatment at providers with which they have an agreement.

Private insurers operating in Denmark usually contract selectively, but this is limited due to the relatively few private hospitals and clinics in many specialty areas. Some contract with suppliers abroad. The choice of providers is based on expertise, quality, available capacity and prices. Insurance companies do not provide access to detailed information about contracts and negotiated prices as this is subject to competition (interview with "Forsikring og Pension", January 27, 2016).

In Sweden, private insurers contract selectively with private providers and select providers on the basis of their competence, capacity, prices and quality. In some cases private providers are offering their services to county councils, and private insurance companies buy surplus capacity. In other cases private providers are oriented exclusively towards the market for VPHI patients. Increasingly, insurance companies are working with a selected network of providers and are developing contracts to align incentives regarding both costs and quality.

\section{Tax-policies to promote VPHI}

The governments in Denmark and Norway have introduced tax-incentives to promote expansion of employment-based VPHI in 2002/2003. Later, the majority of these taxincentives were abolished mainly due to changes in the political majority and the new majorities concern for equity.

In Norway, tax incentives were introduced in 2003. These tax incentives triggered the first wave of growth of the VPHI market. The incentives gave employers and employees tax exemption on private health insurance. Employees were given a tax exemption on the benefit of having medical treatment expenses covered by employer, and employers could deduct the medical expenses on their social security contributions. The tax agreement were conditional on the following conditions. First, only medical treatment aimed at diagnostics, treatments and rehabilitation provided by authorized health personnel were included. Hence, medical services aimed at prevention, cosmetics and infertility treatments were excluded. Second, only treatments that took place in private facilities not financed by the public were included. Third, the tax exemptions only applied to hospital treatment and treatment that would be otherwise reimbursable in the public system. Finally, the tax exemption were only applicable to expenses for treatment and hotel services at treatment facilities, the corresponding travel expenses, the medical follow-up and rehabilitation provided by health personnel and conditioned on the referral from a doctor (Finansdepartementet 2003). The tax incentives were removed in 2006 after the 2005 Parliament election that gave a CenterLeft majority. In 2010 a proposal to reintroduce tax-exemption for employment-based VPHI was rejected (Representantforslag 41S 2009-2010). Currently, employment-provided health insurance in Norway is subject to tax on benefit as it was before the introduction of tax exemptions. 
In Denmark tax exemptions for employer-paid private insurance were introduced in 2002. Tax exemptions were applicable to treatment of employees in case of illness and accidents including psychiatric treatment and preventive treatment. It was conditioned on the coverage of all employees in the firms and a referral from a doctor. Cosmetic treatments and infertility treatments were excluded from the tax exemption (Copenhagen Economics, 2008). The tax exemptions resulted in substantial growth of market for supplementary employer-financed private health insurance (CEPOS 2014). In 2012, the majority of the tax exemptions for employment-based private health insurance were abolished ${ }^{10}$ (Skat, 2012) mainly to address concerns related to equity. Employment-paid private health insurance is now taxed as a benefit for the employee with few exceptions. Surprisingly this has not led to a reduction in the number of Danes covered by VPHI after 2012.

Neither the Finnish nor the Swedish government have introduced specific tax policies targeted at stimulating the take up of the employment based VPHI. However, in Finland some tax incentives exist for group policies since private insurance is not taxed as a benefit for employees if it applies to all employees in a firm. The insurance costs of the employer are deducted from the taxable profit of the company (when all employees are insured).

In Sweden there is no tax on benefit from having employer-paid private health insurance. The same rule applies irrespective of all the employees are covered or only a few. However, if the benefit also covers deductibles for the use of services, including copayments to publicly finances services, a small taxable benefit for the employee exists equal to 3 per cent of the annual premium. Insurance signed by the employer can also be paid by individual employees as a reduction of their income before taxes. If so, the insurance is a taxable benefit for the individual. From the employer perspective, premiums for VPHI are a non-deductible expense.

\section{Discussion and conclusions}

The data presented in this paper indicate that VPHI in the Nordic countries play two main roles in relation to the public health care system; a complementary and a duplicate role. Interestingly, both types of insurance are meant to cover risks that are perceived to be low, namely co-payments for public services and worsened health conditions due to late access to care within the public system

Complementary VPHI plays a significant role in Denmark and in Finland, but does not exist in Norway and Sweden. In Denmark it is aimed at reimbursement of services for which high co-payments in public system exist (dentistry, pharmaceuticals, glasses, some types of physiotherapy). Historically such payments were covered by the sickness fund system. When this system was abolished in 1973, it opened up a market that the non-profit insurance company 'danmark' filled. Since then, it has grown to be one of the largest companies in Denmark, and it provides individual insurance policies to cover co-payments within health care.

A similar situation occurs in Finland where the main reason for buying complementary VPHI is the low reimbursement rate of the obligatory public health insurance for medical diagnostics and treatments in the private sector. When public health insurance was introduced in 1964, the average reimbursement rate was set at $60 \%$ of the expenditures. Since the legal (reimbursement) rate is not directly related to the actual prices, but instead to an administratively determined "reimbursement rate", it has been possible to

${ }^{10}$ Exceptions include expenses for prevention and work-related medical problems as well as treatment related to alcohol and drug abuse under condition that it is offered to all employees in the firm and a referral from a doctor. 
lower the real reimbursement rate gradually without the political troubles of changing the law. Currently, the average real reimbursement rate is around $25 \%$ of the expenditures. Interestingly, the function of the Finnish VPHI is largely complementary to the PHI funded system (by covering the high copayments), but at the same time duplicate to the tax funded system as the PHI offers direct access to specialists, and often with less waiting. In the public sector there is a lack of availability for services such as rehabilitation services, and for outpatient medical specialists such as gynecologists, ophthalmologists, pediatricians and psychiatrists. The waiting times for public system dentists, GPs and certain elective surgery operations are often long. A recent study from the metropolitan area of Finland found that private services - often covered by VPHI - actually offer a parallel system for children's ambulatory health care services (Järvelin, Virta, Mikkola 2015).

The absence of complementary insurance in Norway and Sweden can be explained by the fact that services that often are covered by complementary insurance are not part of the public system. Dental treatments for adults and opticians are leading examples. These services are characterized by ex-ante moral hazard and no private insurance companies have entered this market. Another reason is that the governments in Norway and Sweden heavily subsidize some services that often face high co-payments, and thus are candidates for complementary VPHI. Prescription drugs are examples of such services.

Duplicate VPHI exists in all Nordic countries, and is the main VPHI that is offered in Norway and Sweden. This type of coverage is meant to overcome the challenges of limited capacity and long waiting times by providing faster access to examination and treatments. It should however be noted that the expansion of (duplicate) VPHI has taken place at a time when waiting times were reduced in Denmark, Finland, and Sweden (Siciliani et al, 2013). The waiting time for surgery has for example been reduced from about 12 weeks in 2001 to less than 8 weeks in 2011 in Denmark (Christiansen and Bech, 2013). In Norway the picture is different as (median) somatic care waiting times have increased since 2005, but been stable within psychiatric care (Kalseth et al., 2010).

Another rationale for purchasing VPHI is to expand the choice of providers beyond the public sector. However the Nordic countries have implemented reforms that increase the choice of providers irrespectively of VPHI. These reforms were originally set up to provide choice within the public system, but are later expanded to also include private providers: The extended free choice of hospital was introduced in Denmark in 2002 (Sundhedsloven, 2011). In Sweden, the "Choice of provider"-policy came into force in $1^{\text {st }}$ July 2003 (Regeringen, 2002). From January $1^{\text {st }}$ 2015, the new Patient law (2014:821) introduced in Sweden gives individuals a free choice nationally for all primary care and outpatient specialist care service offered by county councils. The current provisions for referrals as applies in the county council of residence determine which services are provided. This means that most Swedes have the possibility to access for example private specialist providers in the Stockholm areas without a referral for outpatient services. In Finland, the Health Care Act in 2010 extended the freedom of choice for both primary and hospital care to cover municipally operated or commissioned private health care units in the entire country in $2014^{11}$. The Finnish PHI has always offered free choice of provider but in the municipal system the choice has traditionally been more limited (Tynkkynen, 2016.) Finally, in Norway the free choice of provider is expanded to include private for-profit providers that do not have a contractual relationship with the regional health care authorities

\footnotetext{
${ }^{11}$ In practice however, the choice has not played a major role in the municipal system since there are in many places problems with access and continuity of care. Finland has had the PHI system parallel to the municipal system already for 50 years. In this sense people have always had an extensive choice if they are able and willing to pay the high co-payments.
} 
(Administrative regulation 29. October 2015). Hence, when it comes to the increased choice of providers, most patients have the choice of treatment in the private sector irrespectively of VPHI. It seems that VPHI thus has little to offer to counteract limited choice.

There might however be other potential advantages of duplicate VPHI seen from the patient perspective. Patients covered by PHI and/or VPHI in Finland can directly access private specialist care without referrals from a primary care physician. Moreover, Anell (2014) indicates that patients can benefit from the fact that insurers in Sweden usually pay private providers based on fee-for-services, whereas public providers are usually payed from county councils based on capitation (primary care) or more or less tight budgets (specialist care). It is well known that fee-for-services reduce the incentives to underprovide services, i.e. select treatments and examinations only on the ground of costs. VPHI can also provide additional benefits for patient in terms of direct access to specialist care.

In spite of the number of positive claims discussed above there are also potential problems associated with VPHI that should not be overlooked. Earlier evidence on determinants of the propensity to purchase VPHI find that higher socio-economic statues (income, education, social class and employment status) are significant, while observable health measures typically are not (e.g. Cameron et al., 1988; van Doorslaer et al, 2004). Furthermore, most studies find that, after controlling for adverse selection, VPHI increases health care consumption due to moral hazard (e.g., Hurd and McGarry, 1997 and Jones et al, 2006). Hence, VPHI might be detrimental for welfare as it is bought primary by low risk patients and does not eliminate (ex post) moral hazard. Future research should investigate if this is the case also in the Nordic countries.

Nevertheless, duplicate private insurance can potentially contribute to higher quality of care when private insurers provide financial incentives for the provider to improve their performance or when the insurers selectively contract with the most effective and competent providers. However, despite these potential benefits that may arise from duplicate VPHI, it can be argued that the main contribution of VPHI is related to complementary covering of co-payments. In this aspect VPHI should be valued high in the Nordic countries where there are strong preferences for equal access to health care. However, in reality the effects of VPHI appear to depend on the way the health system in organized and financed.

We believe a country's specific institutional health care setting shape the market for VPHI. Future research should take a more explorative approach to investigate how the combination of limited capacity, increased use of out-of-pocket payments, and rationing though waiting times have shaped the markets for VPHI in the Nordic countries. Other areas of future research include the implications for population access, the existing regulatory framework related to VPHI, the development of contracts between insurers and providers and payments to providers, and studies of the use of VPHI and for what reasons.

\section{Acknowledgements}

Financial support from the Nordic Research Council (project grant no: 229987/F10) and from the Norwegian Research Council (project grant no: 238133/H10) is gratefully acknowledged. We thank Paul Nystedt, Carl Hampus Lyttkens and Terje P. Hagen for valuable comments on an earlier draft. 


\section{References}

Anell A. (2014). Vilken ojämlikhet är mest rättvis? Patientinflytande och egenavgifter i svensk vård (Which type of inequality is most fair? Patient influence and personal contributions in Swedish healthcare), 3-92.

Cameron A.C., Trivedi P.K., Milne F. and Piggott J. (1988). A microeconometric model of the demand for health care and health insurance in Australia. Review of Economic Studies, 55(1), 85-106.

Christiansen T. and Bech M. (2012). Chapter 6: Review of waiting time policies: Denmark Waiting Time Policies in the Health Sector: What works? In: L. Siciliani, M. Borowitz and V. Moran (eds.) OECD Health policy studies, 115-131.

CEPOS (2014). Halvdelen af danskerne har nu en privat sundhedsforsikring (Half of the Danes now have a private health insurance), www.cepos.dk/sites/cepos.dk/files/media/import/analyser/ notat_halvdelen_af_danskerne_har_nu_en_privat_sundhedsforsikring_apr14.pdf. Accessed 8 January 2016.

Colombo, F. and Tapay N. (2004). Private health insurance in OECD countries. The benefits and costs for individuals and health systems. OECD Health Working Papers No. 15, 3-60.

Federation of Finnish Financial Services (FFFS) (2015). Statistics 2014. www.fkl.fi/en/material/statistics/Statistics/FK-Tilasto-FinancialServicesStatistics2014.pdf. Accessed 8 January 2016.

Finans Norge (2015a). Stadig flere med privat behandlingsforsikring (Finance Norway 2014. An increasing number of private health insurance), www.fno.no/aktuelt/nyheter/2015/08/stadigflere-med-privat-behandlingsforsikring/. Accessed 8 January 2016.

Finans Norge (2015b). Key-Statistics Non-life insurance, www.fno.no/contentassets/840791dfa 41c42429db9306e1e576595/nokkeltall-i-skadeforsikring/key-statistics-non-life-insurance2015.pdf.Accessed 8 January 2016.

Finans Norge (2014). Behandlingsforsikring Statistikk (Finance Norway 2014. Medical treatment insurance Statistics) https://www.fno.no/statistikk/skadeforsikring/Arlige-publikasjoner/ Behandlingsforsikring---kritisk-sykdom-og-barneforsikring/ Accessed 8 January 2016.

Finansdepartementet (2003). Forskrift 11. september 2003 om endring av forskrift til skatteloven av 26.mars 1999 nr.14 Arbeidsgivers dekning av ansattes behandlingsutgifter (Regulation 11 September 2003 amending regulation to the Tax of 26 March 199914 employer's coverage of employees' medical expenses).

Forsikring og Pension (2013). Hvad er en sundhedsforsikring (Insurance and Pension 2014. What is a health insurance), www.forsikringogpension.dk/temaer/sundhedsforsikringer/fakta-omsundhedsforsikringer/Sider/fakta-om-sundhedsforsikringer.aspx. Accessed 8 January 2016.

Forsikring og Pension (2014a). Sundhedsforsikringer - hovedtal 2003-2014 (Insurance and Pension 2014. Health insurance - key figures from 2003 to 2014), www.forsikringogpension.dk/ presse/Statistik_og_Analyse/statistik/forsikring/antalpolicer/Documents/Sundhedsforsikringer .pdf. Accessed 8 January 2016.

Forsikring og Pension (2014b). Sundhedsforsikring - Kvartalsvise markedsandele (Insurance and Pension 2014. Health Insurance - Quarterly market share), www.forsikringogpension.dk/ presse/Statistik_og_Analyse/statistik/forsikring/markedsandele/Documents/Kvartalsvise_mar kedsandele_sundhedsforsikring.pdf. Accessed 8 January 2016.

Försäkringskassan (2012). Abonnemangstandvård. Socialförsäkringsrapport 2012:2,5-46

Hurd M.D. and McGarry K. (1997). Medical insurance and the use of health care services by the elderly. Journal of Health Economics, 16(2), 129-154.

Jones A.M., Koolman X. and Van Doorslaer E. (2006). The impact of supplementary private health insurance on the use of specialists in selected European countries. Annales d'Economie et de Statistique, 83-84: 251-275. 
Järvelin J., Virta L. and Mikkola H. (2015). Hoitoon yksityiselle vai julkiselle sektorille? Alle 7vuotiaiden lääkärissäkäynnit pääkaupunkiseudulla. (To a public or private doctor? The use of medical services by children aged 6 or less in the metropolitan area of Finland). Finnish Medical Journal, 70(47), 3199-3206.

Kalseth, B. (2010). Ventelistestatistikk I Norge, Sverige, Danmark, Finland, Skottland og EnglandDatagrunnlag og anvendelse. SINTEF Rapport A16216, 5-82.

Kiil, A. (2012). What characterises the privately insured in universal health care systems? A review of the empirical evidence. Health Policy, 106(1), 60 - 75.

Manifest (2009). Klassedelt helsevesen? Om utbredelsen av privat helseforsikring i Norge (Class divided healthcare? The distribution of private health insurance in Norway).

Mossialos, E. and Thomson S. (2004). Voluntary health insurance in the European Union. Copenhagen: World Health Organization, 7-206.

OECD (2004). Proposal for a taxonomy of health insurance OECD health project. Paris: Organisation of Economic Cooperation and Development, 5-21

OECD (2015). OECD Health Statistics 2015. Definitions, sources and methods. www.oecd.org/health/health-data.htm.

Pedersen (2005). Voluntary supplementary health insurance in Denmark. Public Finance and Management, 5(4), 544-566.

Regeringen (2002). Redogörelse för en överenskommelse mellan staten och Landstingsförbundet om visse ersättningar til hälsa- och sjukvården för år 2003 (Presentation of an agreement between the State and County Councils for certain remunerations to the health care system in 2003). Regeringens skrivelse, Vol. 03:51.

Representantforslag 41S (2009-2010). fra stortingsrepresentantene Per Arne Olsen, Harald T. Nesvik og Christian Tybring-Gjedde. Dokument 8:41S (Suggestions from representatives 41S (2009-2010), from parliament representatives Per Arne Olsen, Harald T. Nesvik and Christian Tybring- Pike. Document 8: 41s).

Ringård Å., Sagan A., Sperre Saunes I. and Lindahl A.K. (2013). Norway. Health system review. Health System in Transition, 15(8), 1-162

Sagan A., and Thomson S. (2015). Voluntary health insurance in Europe: demand, supply and implications for health system performance. Copenhagen: WHO Regional Office for Europe on behalf of the European Observatory on Health Systems and Policies.

Siciliani L., Borowitz M. and Moran V. (2013). Waiting Time Policies in the Health Sector: What Works? OECD Health Policy Studies,19-32.

Skat (2012). Nyt om beskatning og indberetning af sundhedsforsikring fra 29 mar 2012 (News on taxation and reporting of health insurance from May 29, 2012). www.skat.dk/ SKAT.aspx?oId=2041964\&vId=0. Accessed 8 January 2016.

Skoglund C. (2012). Privata sjukvårdsförsäkringar i Sverige - omfattning och utveckling. Rapport till SKL, 2-49.

Svensk Försäkring (2013). Vad är en privat sjukvårdsförsäkring? (What is a private health insurance?) www.svenskforsakring.se/Huvudmeny/Fakta--Statistik/Fakta/Undersidor/Vad-aren-privat-sjukvardsforsakring1/. Accessed 8 January 2016.

Svensk Försäkring (2013). Så fungerar en sjukvårdsförsäkring. (This is how the health care insurance works) www.svenskforsakring.se/Huvudmeny/Fakta--Statistik/Fakta/Undersidor/ Vad-ar-en-privat-sjukvardsforsakring_/. Accessed 8 January 2016.

Svensk Försäkring (2015). Sjukvårdsförsäkringsstatistik. (Health insurance statistics) www.svenskforsakring.se/Huvudmeny/Fakta--Statistik/Statistics-list/Sjukvardsstatistik/ Sjukvardsforsakringsstatistik-2015/. Accessed 8 January 2016.

Sygeforsikring "Danmark" (2014). Årsrapport 2014 (Health Insurance "Denmark" 2014. Annual Report 2014). www.sygeforsikring.dk/Default.aspx?ID=23. Accessed 8 January 2016. 
Tynkkynen L-K., Chydenius M., Saloranta A., Keskimäki I. (2016). Expanding choice of primary care in Finland: much debate but little change so far. Health Policy, Jan 19.

Valtonen H., Kempers J. and Karttunen A. (2014). Supplementary health insurance in Finland. Consumer preferences and behaviour. Helsinki, KELA Working paper no. 65/2014, 5-55

Van Doorslaer E.C., Masseria C., the OECD Health Equity Research Group Members (2004). Income-related Inequality in the Use of Medical Care in 21 OECD Countries. Towards HighPerforming Health Systems: Policy Studies from the OECD Health Project. Paris: OECD, 3-88

Vuorenkoski, L. (2008). Finland. Health System Review. In Health Systems in Transition 10(4), eds. Mladovsky and Mossialos.

(C) 2016 by the author(s). This article is an open access article distributed under the terms and conditions of the Creative Commons Attribution license (http://creativecommons.org/licenses/by/4.0/). 